\title{
Pathogen to Endophytic Transmission in Fungi- A Proteomics Approach
}

Thulasi G Pillai*

Department of Chemical engineering, Indian Institute of Technology Bombay, Powai, Mumbai, India

Received: 10 February, 2017; Accepted: 30 March, 2017; Published: 20 April, 2017

*Corresponding author: Thulasi G Pillai, Department of Chemical engineering, Indian Institute of Technology Bombay, Powai, Mumbai-400076, India, E-mail: thulasigpillai@gmail.com

\begin{abstract}
Fungi are a model organism for eukaryotic kingdom. Endophytic fungi have important role in plant microbiome. The endophytic fungi are thought to have evolved from parasites or pathogens through an extension of latency periods and reduction of virulence. The endophytic fungi, Colletotrichum are source of valuable compounds, useful in pharmaceutical/agricultural industry. The genus Colletotrichum consists of 29 to 700 species. It is a wellknown pathogen for long period and at the same time a well-known endophyte. This transition of the fungus from one state to another is interesting. The mechanism of transition from pathogen to endophyte is not yet studied. Chances of genetic drift were proposed earlier but not yet studied. In this review, we try to apply protein profiling as a powerful tool to study the transition of the fungi as a pathogen to endophyte (Parasitism to mutualism).
\end{abstract}

Keywords: Fungi; Colletotrichum gloeosporiodes; Pathogen; Endophyte; Protein profiling

\section{The Kingdom fungi}

Fungi are important group of organism on earth as they play important roles in different milieu. Right from the discovery of the first antibiotic Penicillin, a significant milestone in the human history by Alexander Fleming in 1928, fungi, has been used for their capacity to produce many compounds in application both in medicine and industry. Fungi are important secondary metabolite producers, serving mankind. The kingdom fungi, the Mycota, is the sister taxon to the multicellular animals (Metazoa) [1-2]. Over 1.5 million members of the Fungal Kingdom impact nearly all other forms of life as either friend or foe [3]. Fungi possess some of the compact eukaryotic genomes and the genome expansions can be hypothesized as an adaptation to their parasitic lifestyle [4]. The Ascomycota genomes which are obligately parasitic and have greatly expanded genomes containing large numbers of transposable elements [4-5]. Some of the fungal species are of crucial significance for their physiological and symbiotic abilities like mycorrhizal associations which at times are crucial for plant growth, development and fruiting [6]. Proteomic studies of filamentous fungi were started by Lim, et al. on Trichoderma reesei cell envelope proteins and on Aspergillus fumigates glycosyl phosphatidyl inositol-anchored proteins by Bruneau, et al. $[7,8]$. After that a good number of studies have been published on fungal proteomics [9]. This review focus on the genus Colletotrichum.

\section{The genus Colletotrichum}

Division - Ascomycota

Class - Sordariomycetes

Order-Glomerellales

Family - Glomerallaceae

The genus Colletotrichum comprises $\sim 600$ species [10]. Exist in two stages - telomorph (sexual stage) called as Glomerella cingulata and anamorph (asexual) Colletotrichum gloeosporiodes. The generic name Colletotrichum was introduced by Corda for C.lineola, a species found associated with a member of the Apiaceae in the Czech Republic [11]. It attacks over 3,200 species of monocot and dicot plants. Distribution wise Colletotricum has Cosmopolitan nature. Almost all of the plants are susceptible to one or more species of Colletotricum.

\section{Colletotrichum gloeosporiodes as a pathogen}

Colletotrichum gloeosporioides was a pathogen for long period. The genus Colletotrichum consists of 29 to 700 species. C. gloeosporoides has a long history as a model pathogen for fundamental, biochemical, physiological and genetic studies. Their biotrophic life strategies contribute their prominence as symptomless endophytes of living plant tissues. The organism interacts with numerous plant species explicitly as indicative pathogens and cryptically as asymptomatic pathogens. It is not clear whether these contrasting ecological modes are optional strategies expressed by individual Colletotrichum species or whether species ecology is explicitly pathogenic or endophytic. The infection strategy of this organism is a multistage hemibiotrophy [12]. Colletotrichum are endophytes as well as disease agents of conifers and ferns [13-18]. They are associated widely with both herbaceous and woody plants, though the latter appear mainly to contain colonies in fruits, leaves and 

Approach

other non-lignified tissues. There is a change in their character from intracellular hemibiotrophy to subcuticular nectrophy. The organism develops specific structures which are particular to pathogens - germ tube, appressolia, intracellular hyphae and secondary nectrotrophic hyphae.

\section{Colletotrichum gloeosporiodes as an endophyte}

The ecological significance of endophytism is unclear. The establishment of endophytic association with plants are interesting, the initial steps being the same - recognition, germination and penetration and then a quiescence stage is developed. There may be some mechanism to avoid recognition also. A gene has been cloned from Colletotrichum gloeosporioides which is switched on during the initial phase of colonisation and switched off later during the necrotrophic phase. This gene encodes a glycoprotein that resembles plant cell wall proteins which is believed to coat the hyphae that the plant is unable to recognise as alien. They are pathogenic on the main host species but symptomless endophytes on 'non -disease' host species, providing mutualistic benefits such as disease resistance, drought tolerance and growth enhancement. This differential behaviour may result from differences in fungal gene expression in response to the plant or differences in the ability of the plant to respond to the fungus. Mutualistic endophytes can be evolved from parasitic or pathogenic fungi $[19,20]$.

\section{Host - Parasite Interaction}

Endophytism, the capacity of an organism to colonize tissues of a host plant without causing disease symptoms, is a complex process influenced by several physiological and environmental factors. Travel of a pathogen to endophyte in a plant is really audacious. The journey through co-evolution produces lot of changes both in endophytic partner and also in the host. The biotrophic life strategies adopted by Colletotrichum species may also contribute to their prominence as symptomless endophytes of living plant tissues [21-23]. Research into the molecular basis of host-parasite interactions in Colletotrichum is currently highly active, and such approaches will dominate research in the future into the extent of host specificity exhibited by Colletotrichum species [24]. Constant monitoring of the tree for disease symptoms are done to check whether the endophyte is transformed to pathogen. There are no reports for that. No angiosperm that does not harbour endophytic Colletotrichum colonies are known so far. There are many reports about isolation of taxol, the anticancer drug from Colletotrichum gloeosporioides from different plants [25].

\section{The Genome}

The estimated total genome size of Colletotrichum gloeosporioides is 55.6 MB [26]. About 15469 genes are predicted in C. gloeosporoides. The first applications of DNA sequence data to distinguish between Colletotrichum species were published by Mills et al. and Sreenivasa Prasad et al. who identified sequence variation in the ITS1 region of nr DNA between six species of Colletotrichum, as well as detecting polymorphisms in the same region between strains of $C$. gloeosporioides from different hosts
$[27,28]$. We isolated C.gloeosporioides as a host specific endophyte from the forest tree Cyanometra travancorica [29]. Genomic analyses of the fungi have revealed that the gene densities are below the genome average and only two of the scaffolds have GC contents of below $50 \%$ and the genes encode proteins like fungal effectors, proteins that have important role in disabling the host defense system. Evidence of molecular mimicry for the production of subtilisin by horizontal gene transfer from the plants have been reported [30]. Colletotrichum gloeosporoides was identified as true endophyte from Cynometra travancorica, possessing dispensable, potential pathogenicity - associated chromosomes that can be horizontally transferred between compatible strains [31].Their biotrophic life strategies contribute their prominence as symptomless endophytes of living plant tissues. Chances of genetic transfer are more as it is evident from the fact that the secondary metabolites which are produced by the plants are now produced by the endophytic partner.

Eg: Taxomyces andreanae which produces taxol.

\section{Application of Proteomics}

Now a major challenge in modern fungal biology is to understand the expression, function and regulation of the entire set of proteins encoded by fungal genomes. This is the aim of newly emerging field of proteomics, i.e., fungal proteomics. This information will be invaluable for understanding plant-fungal interactions, pathogenesis and fungal colonization.

Proteomics complements other functional genomics approaches including transcriptomics [32]. Colletotrichum exhibit different forms in their life cycle even within a single species, like biotrophy, necrotrophy, endophytic and latency. Each stage brings about different interaction and during these stages many proteins are released due to differential gene expression.

Biotrophy $\rightarrow$ Necrotrophy $\rightarrow$ Endophytic $\rightarrow$ Latency

Biotrophic fungi have variations in their tubular cells, the hyphae. Haustorium is the specialized hyphae.

Necrotrophic fungi secrete toxins and kill host cells as soon as they enter. They take the nutrients from plants and kill them. Endophytic fungi doesn't sporulate at all. They can be seen inside the cell. They live in mutualism. Latency period is that between sporulation and germination. It remains in an inactive stage and there will be no growth.

Protein profiling can give an overall picture about the conversion of a pathogen to an endophyte. There are reports for the presence of plant like S8A - subtilisin in the genome of Colletotrichum. Evidence of molecular mimicry for the production of subtilisin by horizontal gene transfer from the plants has been reported [33]. These proteins show evidence of lateral gene transfer from plants to a Colletotrichum ancestor. It's possible that Colletotrichum acquire and use plant like subtilisins to manipulate host metabolism [27]. The increase of plant-pathogen interaction analysis, focused on the plant-fungus association is a topic of rising interest in the last five years; even when the limitation in sequence availability in public databases is also 
challenging [34]. Hence it's a unique opportunity for comparative proteomic analysis of their association with plants.

\section{Protein Isolation}

Protein extraction is very important step for fungal proteomics as it influences protein function, yield, and the structural integrity of specific target proteins. For adequate release of intracellular proteins, cell wall lysis of the fungi should be perfect. As filamentous fungi possess rigid cell wall, an effective strategy has to be followed for fungal proteomics study. Shimizu and Wariishi has devised an appropriate method for lysing the fungal cell wall by generating protoplasts where 2DE patterns were better visualised than proteins isolated from disrupting the fungal cell wall using SDS extraction [35]. The protein extracted is subjected to Tri Chloro Acetic Acid (TCA) precipitation for purification to minimise problems due to contaminants during isoelectric focusing [36]. Proteins obviously play critical roles in diverse biological processes through interactions with other proteins, DNA, RNA, and small molecules both inside and outside cells. Once the cells are lysed, the protein solution is often purified via Trichloroacetic Acid (TCA) precipitation to remove contaminants that can be problematic during isoelectric focusing [36] (figure 1).

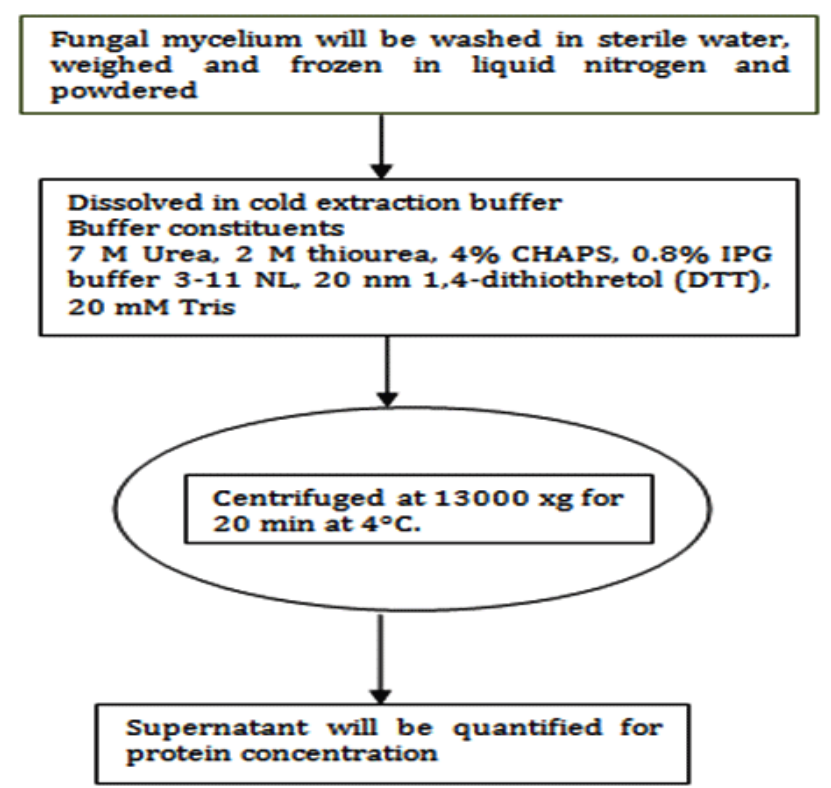

Figure 1: Protein Isolation

\section{Protein Identification}

1.Sorting of mycelial proteins are done by two-dimensional electrophoresis [2-DE or 2D-DIGE/MS] by the method of Olja B, et al. [37].

2.Differentially expressed spots are subjected to in gel trypsin digestion [38].
3.After crystallization by standard procedures, the peptides are analysed by MALDI-TOF MSor MALDI-TOF/TOF MS/MS using Proteomics analyser mass spectrometer [39]. Peptides are identified by MASCOT search engine.

\section{Analysis of the intracellular proteome}

Protein regulation, function and expression of fungal genomes are really challenging.

Grinyer, et al. used a combination of 2D-PAGE and mass spectrometry for the identification of proteins from filamentous fungi [40]. Hernández-Macedo, et al. carried out fungal protein vizualisation by 2DPAGE [41]. A filamentous fungi used as a model organism is Aspergillus sp. The majority of the Aspergillus proteome research is still represented by quantitative 2D studies and less than $10 \%$ of the predicted whole proteome of Aspergillus sp [42-44]. Has been identified and quantified until now. Some of the fungal proteins which are studied are shown in Table 1.

Table 1: Some of the fungal proteins which are studied are detailed below

\begin{tabular}{|c|c|c|}
\hline Fungi & Protein & Author \& Year \\
\hline A. fumigates & $\begin{array}{c}\text { Mycellial intracellular } \\
\text { proteome }\end{array}$ & $\begin{array}{c}\text { Carberry, et al. } \\
\text { [45] }\end{array}$ \\
\hline A. fumigates & $\begin{array}{c}\text { Intracellular proteome } \\
\text { of dormant conidia }\end{array}$ & $\begin{array}{c}\text { Teutschbein, et } \\
\text { al. [46] }\end{array}$ \\
\hline $\begin{array}{c}\text { Aspergillus } \\
\text { niger }\end{array}$ & $\begin{array}{c}\text { Cytosolic proteome } \\
\text { reference map }\end{array}$ & Lu, et al. [47] \\
\hline $\begin{array}{c}\text { Penicillium } \\
\text { chrysogenum }\end{array}$ & $\begin{array}{c}\text { Intracellular proteome } \\
\text { reference map }\end{array}$ & Jami, et al. [18] \\
\hline
\end{tabular}

The majority of above proteins are involved in cellular metabolism, protein synthesis, transport processes and cell cycle. The intracellular proteome of dormant conidia (asexually produced spores) of $A$. fumigates are required for stress tolerance and rapid reactivation of metabolic processes. The cytosolic proteome reference map of the well-known producer of primary metabolites and extracellular proteins Aspergillus niger are also characterized.

One of the constrain of proteomic analysis of filamentous fungi is that only less than $10 \%$ of the predicted whole proteome are identifiable. Under laboratory conditions, only a fraction of the total genome gives rise to proteins. Expression of other proteins will be under different nutritional and environmental conditions in nature.

\section{Proteomic Mapping - Uses}

1.Complete understanding of different mechanisms and expression factors which are involved in conversion of a pathogen to endophyte.

2.Develop systematic understanding of virulence factors in pathogenic fungi. Fernandez-Acero, et al. [48]. 
3.Providing insight related to systematic metabolic flux changes.

\section{Conclusion}

The entire plant kingdom on this earth is host for fungal endophytes. The fungal endophytes have gained importance in the present context to such an extent that active insight into the structure, biology, metabolism and expression are important to study as they play an important role in medicine, agriculture and industry. There are many reports for the endophytic fungi Colletotrichum, producing anticancer drugs like taxol and camptothecin. The large scale productions of these drugs in lab are not successful so far. There can be certain factors which are responsible for these differences. Proteomic analysis can give a complete understanding about the fungi. Our study organism C. gloeosporoides can be utilized as a model in fungal proteomics. Studies are underway.

Endophytic fungi are an important bio resource which are not utilised properly due to lack of understanding about the physiological and biochemical aspects. If utilised properly, these organism can have lot of application in medicine, industry and agriculture.

Proteomic analysis is a powerful tool capable of resolving thousands of proteins and thereby allows a systematic understanding of the molecular events that occur within an organism's various physiological states, protein expression level of specific genes, and through cellular fractionation can provide spatially specific information on protein expression. For C. gloeosporiodes, post genomic studies (especially in the area of proteomics) are just beginning to take place and considering the importance of the organism as both a pathogen and endophyte, it is surprising that proteome profiling is yet to be done. Our current studies are focussed on the same.

\section{References}

1. Wainright PO, Hinkle G, Sogin ML, Stickel SK. Monophyletic origins of the metazoa: an evolutionary link with fungi. Science. Science. 1993;260(5106):340-342.

2. Liu Y, Steenkamp ET, Brinkmann H, Forget L, Philippe H, Lang BF. Phylogenomic analyses predict sister group relationship of nucleariids and fungi and paraphyly of zygomycetes with significant support. BMC Evol Biol. 2009;9:272.

3. Hawksworth DL. The fungal dimension of biodiversity: magnitude, significance, and conservation. Mycol Res. 1991;95:641-645.

4. Martin F, Kohler A, Murat C, Balestrini R, Coutinho PM, Jaillon O, et al. Perigord black truffle genome uncovers evolutionary origins and mechanisms of symbiosis. Nature. 2010;464(7291):1033-1038.

5. Spanu PD, Abbott JC, Amselem J, Burgis TA, Soanes DM, Stuber K, et al. Genome expansion and gene loss in powdery mildew fungi reveal tradeoffs in extreme parasitism. Science. 2010;330(6010):1543-1546.

6. Wang B, Qiu YL. Phylogenetic distribution and evolution of mycorrhizas in land plants. Mycorrhiza. 2006;16:299-363.
7. Lim D, Hains P, Walsh B, Bergquist P, Nevalainen H. Proteins associated with the cell envelope of Trichoderma reesei: A proteomic approach. Proteomics. 2001;1(7):899-909.

8. Bruneau JM, Magnin T, Tagat E, Legrand R, Bernard M, Diaquin $M$, et al. Proteome analysis of Aspergillus fumigates identifies Glycosylphosphatidylinositol-anchored proteins associated to the cell wall biosynthesis. Electrophoresis. 2001;22(13):2812-23.

9. Breakspear A, Momany M. The first fifty microarray studies in filamentous fungi. Microbiology. 2007;153:7-15.

10. Crous PW, Gams W, Stalpers JA, Robert V, Stegehuis, G. MycoBank: an online initiative to launch mycology into the 21st century. Stud Mycol. 2004;50:19-22.

11. Corda ACI. Die Pilze Deutschlands. In: Sturm J (ed) Deutschlands Flora in Abbildungen nach der Natur mit Beschreibungen. Sturm, Nürnberg. 1831;3:33-64.

12. Perfect SE, Hughes HB, O'Connell RJ, Green JR. Colletotrichum: a model genus for studies on pathology and fungal plant interactions. Fungal Genet Biol. 1999;27(2-3):186-198.

13. Dingley JM, Gilmour JW. Colletotrichum acutatum Simmds. f. sp. Pinea associated with "terminal crook" disease of Pinus spp. New Zealand Journal of Forestry Science. 1972;2:192-201.

14.Wang W, Tang JH, Wang YC. Molecular detection of Colletotrichum lindemuthianum by duplex PCR. Journal of Phytopathology. 2008;156:431-437.

15. Joshee S, Paulus BC, Park D, Johnston PR. Diversity and distribution of fungal Foliar endophytes in New Zealand Podocarpaceae. Mycological Research. 2009;113:1003-1015.

16. Damm U, Cannon PF, Woudenberg JH, Crous PW. The Colletotrichum acutatum species complex. Stud Mycol. 2012;73(1):37-113.

17. Leahy R, Schubert T, Strandberg J, Stamps B, Norman D. Anthracnose of leather leaf fern. Plant Pathology Circular. 1995;372:4.

18. Mackenzie SJ, Peres NA, Barquero MP, Arauz LF, Timmer LW. Host range and genetic relatedness of Colletotrichum acutatum isolates from fruit crops and leather leaf fern in Florida. Phytopathology. 2009;99(5):620-31.

19. Carroll G. Forest endophytes: pattern and process. Can. J. Bot.1995;73:316-1324

20. Saikkonen K, Faeth SH, Helander M, Sullivan TJ. Fungal endophytes: a continuum of interactions with host plants. Annual Review of Ecology and Systematics. 1998;29:319-343.

21.Lu G, Cannon PF, Reid A, Simmons CM. Diversity and molecular relationships of endophytic Colletotrichum isolates from the Iwokrama Forest Reserve, Guyana. Mycological Research. 2004;108:53-63.

22. Rojas EI, Rehner SA, Samuels GJ, Van Bael SA, Herre EA et al. Colletotrichum gloeosporioides s.l. associated with Theobroma cacao and other plants in Panama: multilocus phylogenies distinguish hostassociated pathogens from asymptomatic endophytes. Mycologia. 
2010; 102:1318-1338.

23. Yuan ZL, Su ZZ, Mao LJ, Peng YQ, Yang GM, et al. 2011. Distinctive endophytic fungal assemblage in stems of wild rice (Oryza granulata) in China with special reference to two species of Muscodor (Xylariaceae). J Microbiol. 2011;49(1):15-23.

24. O'Connell RJ, Thon MR, Hacquard S, Amyotte SG, Kleemann J, Torres $\mathrm{MF}$, et al. Life-style transitions in plant pathogenic Colletotrichum fungi deciphered by genome and transcriptome analyses. Nat Genet. 2012;44(9):1060-5.

25. Gangadevi V, Muthumary J.Isolation of Colletotrichum gloeosporioides, a novel endophytic taxol-producing fungus from the leaves of a medicinal plant, Justicia gendarussa. Mycologia balcanica. 2008;5:1-4.

26. Gan P, Ikeda K, Irieda H, Narusaka M, O'Connell RJ, Narusaka Y, et al. Comparative genomic and transcriptomic analyses reveal the hemibiotrophic stage shift of Colletotrichum fungi. New Phytol. 2013;197(4):1236-49.

27. Armijos Jaramillo VD, Vargas WA, Sukno SA, Thon MR. Horizontal transfer of subtilisin gene from plants into the ancestor of the plant pathogenic fungal genus Colletotrichum. PLoS One. 2013;8(3):e59078.

28. Mills RR, Sreenivasaprasad S, Brown AE. Detection and differentiation of Colletotrichum gloeosporioides isolates using PCR. FEMS Microbiology Letter. 1992;98(1-3):137-143. doi: 10.1111/j.15746968.1992.tb05503.x

29. Sreenivasaprasad S, Brown AE, Mills PR. DNA sequence variation and interrelationships among Colletotrichum species causing strawberry anthracnose. Physiology and Molecular Plants Pathology 1992;41:265-281.

30. Thulasi GP, Jayaraj R. Colletotrichum gloeosporioides: A true endophyte of the endangered tree, Cynometra travancorica in the Western Ghats. J Plant Pathol Microb. 2014;6:267.

31. Thulasi GP. Genomic analysis of Colletotrichum gloeosporiodes, endophytic fungi, Lifestyle transition in host. J of Proteins and proteomics. 2014;5(3):142.

32. Bhadauria V, Zhao WS, Wang LX, Zhang Y, Liu JH, Yang J, et al. Advances in fungal proteomics. Microbiol Res. 2007;162(3):193-200.

33. Richards TA, Soanes DM, Foster PG, Leonard G, Thornton CR, Talbot NJ. Phylogenomic analysis demonstrates a pattern of rare and ancient horizontal gene transfer between plants and fungi. Plant Cell. 2009;21(7):1897-911.

34. Mehta A, Brasileiro AC, Souza DS, Romano E, Campos MA, Grossi-de-Sá MF, et al. Plant pathogen interactions: what is Proteomics telling us? FEBS J. 2008;275(15):3731-3746.

35. Shimizu M, Wariishi H. Development of a sample preparation method for fungal proteomics. FEMS Microbiol Lett. 2005 ;247(1):17-22.

36.GE Healthcare. 2-D electrophoresis: Principles and methods. 2005.

37. Olja B, Stanislav M, Franci C, Branka J. Proteome analysis of the plant pathogenic fungus Monilinia laxa showing host specificity. Food
Technol. Biotechnol 2012:50:326-333.

38. Carlos Eduardo a Souza, João Paulo a Rego, Carlos H Lobo, José Tadeu a Oliveira, Fábio CS Nogueira, Gilberto B Domont, et al. Proteomic analysis of reproductive tract fluids from tropically- adapted Santa Ines rams. J. Proteomics 2012;75:4436-4456.

39. Gómez-Vidal S, Salinas J, Tena M, Lopez-Llorca LV. Proteomic analysis of date palm (Phoenix dactylifera L.) responses to endophytic colonization by entomopathogenic fungi. Electrophoresis. 2009;30(17):2996-3005.

40.Grinyer J, Hunt S, McKay M, Herbert BR, Nevalainen H. Proteomic response of the biological control fungus Trichoderma atroviride to growth on the cell walls of Rhizoctonia solani. Curr Genet. 2005;47(6):381-388.

41.Hernández-Macedo ML, Ferraz A, Rodríguez J, Ottoboni LM, De Mello MP. Iron-regulated proteins in Phanerochaete chrysosporium and Lentinula edodes: Differential analysis by sodium dodecyl sulfate polyacrylamide gel electrophoresis and two-dimensional polyacrylamide gel electrophoresis profiles. Electrophoresis. 2002;23:655-661.

42. Carberry S, Doyle S. Proteomic studies in biomedically and industrially relevant fungi. Cytotechnology. 2007;53(1-3):95-100.

43. Kim Y, Nandakumar MP and Marten MR. The state of proteome profiling in the fungal genus Aspergillus. Brief Funct Genomic Proteomic.2008;7:87-94.

44. Kniemeyer O, Lessing F, Scheibner O, Hertweck C, Brakhage AA. Optimisation of a 2-D gel electrophoresis protocol for the humanpathogenic fungus Aspergillus fumigatus. Curr Genet. 2006;49(3):17889.

45. Carberry S, Neville CM, Kavanagh KA, Doyle S. Analysis of major intracellular proteins of Aspergillus fumigatus by MALDI mass spectrometry: Identification and characterization of an elongation factor 1B protein with glutathione transferase activity. Biochem Biophys Res Commun. 2006;341(4):1096-104.

46. Teutschbein J, Albrecht D, Pötsch M, Guthke R, Aimanianda V, Clavaud C, et al. Proteome Profiling and Functional Classification of Intracellular Proteins from Conidia of the Human-Pathogenic Mold Aspergillus fumigatus. J Proteome Res. 2010;9(7):3427-3442. doi: 10.1021/pr9010684

47.Lu X, Sun J, Nimtz M, Wissing J, Zeng AP, Rinas U. The intra- and extracellular proteome of Aspergillus niger growing on defined medium with xylose or maltose as carbon substrate. Microb Cell Fact. 2010;9:23.

48. Fernández-Acero FJ, Jorge I, Calvo E, Vallejo I, Carbú M, Camafeita E, et al. Two-dimensional electrophoresis protein profile of the phytopathogenic fungus Botrytis cinerea. Proteomics. 2006;6 Suppl 1:S88-96. 